\title{
KNOWLEDGE SHARING, INNOVATION CAPABILITY, RESPONSIVE CAPABILITY, AND MARKETING PERFORMANCE: AN EMPIRICAL STUDY AT UPN "VETERAN" JAWA TIMUR
}

\author{
Rangga Restu Prayogo ${ }^{* 1}$ and Lia Nirawati**) \\ *) Department of Management, Universitas Negeri Medan \\ J1. William Iskandar No. 104, Deli Serdang 20371 \\ **) Department of Business Administration, Universitas Pembangunan Nasional "Veteran" Jawa Timur \\ Jl. Rungkut Madya, Surabaya, Indonesia 60293
}

\begin{abstract}
Business organizations are required to be able to do effective marketing. Market change demands a business organization to have a marketing capability on innovation and responses in making a product to be competitive; therefore, it should create a quality product. Creating a quality product is influenced by the knowledge of products to be created so as to produce good marketing performance. The purposes of this study were to see how big an influence towards knowledge sharing innovation capability, and to identify the capability to respond to the market and performance marketing. A questionnaire was given to students who were in the university environment by using purposive sampling with accidental sampling. Reliability and validity were measured through the median and variation analysis of Cronbach's alpha, and Analysis using SEM model structure with SMARTPLS was used to test the relationship between research variables using 100 respondents. The results showed that sharing knowledge has a positive and significant effect on the capabilities of innovation and responsive capabilities, but insignificant effect on marketing performance. The responsive capability of innovation and capability on marketing performance are positive and significant.
\end{abstract}

Keywords: knowledge sharing, marketing capability, innovation capability, responsive capability, marketing performance

\begin{abstract}
Abstrak: Organisasi bisnis dituntut untuk dapat melakukan pemasaran yang efektif. Perubahan pasar menuntut organisasi bisnis untuk memiliki kemampuan pemasaran dalam inovasi dan respons dalam membuat suatu produk menjadi kompetitif; oleh karena itu, ia harus menciptakan produk yang berkualitas. Menciptakan produk yang berkualitas dipengaruhi oleh pengetahuan produk yang akan diciptakan sehingga menghasilkan kinerja pemasaran yang baik. Tujuan dari penelitian ini adalah untuk melihat seberapa besar pengaruh terhadap kemampuan inovasi berbagi pengetahuan, dan untuk mengidentifikasi kemampuan untuk merespon pasar dan pemasaran kinerja. Sebuah kuesioner diberikan kepada siswa yang berada di lingkungan universitas dengan menggunakan purposive sampling dengan accidental sampling. Reliabilitas dan validitas diukur melalui median dan analisis variasi alpha Cronbach, dan Analisis menggunakan struktur model SEM dengan SMARTPLS digunakan untuk menguji hubungan antara variabel penelitian menggunakan 100 responden. Hasil penelitian menunjukkan bahwa berbagi pengetahuan memiliki pengaruh positif dan signifikan terhadap kemampuan inovasi dan kemampuan responsif, tetapi tidak berpengaruh signifikan terhadap kinerja pemasaran. Kemampuan inovasi dan kapabilitas responsif terhadap kinerja pemasaran adalah positif dan signifikan.
\end{abstract}

Kata kunci: berbagi pengetahuan, kapabilitas pemasaran, kapabilitas inovasi, kapabilitas responsif, kinerja pemasaran

${ }^{1}$ Corresponding author:

Email: ranggarestuprayogo@gmail.com 


\section{INTRODUCTION}

Marketing plays an important role in determining the orientation and strategy of an organization's business performance results (Prayogo and Nirawati, 2017). The ability to obtain and perform the transformation of "tangible" or "intangible" resources is considered important to specify the value creation and competitive advantage for business organizations (Chenic et al. 2013). Dynamic market changes and is fragmented to demanding business organization in order to make use of the knowledge of the market to be important to conduct technological innovations (Cacciolatti and Lee, 2016). The questions of how business organizations deploy resources to serve customers well, how to better understand the effects and marketing undertaken by business organizations and how marketing capabilities affect the performance of the organization's business in the long run are the most important parts to be understood by business organizations (Angulo-Ruiz et al. 2018). Marketing focuses on the creation of customer requests and how to offer customers on the value of the product (Kladou et al. 2017). On the other hand, the operation focuses on inventory management to meet customer demand. All functional areas of business contribute to the delivery of goods and services, but the marketing and operation having two major functions add and create value for the customer as a quality product (Nath et al. 2010). One of the business organizations that is developing knowledge about products and marketing capabilities to improve the performance of business organization is a business incubator in the Department of Business Administration at UPN "Veteran". Business incubator as a container for a student for selling all of the results of creativity and innovation in a variety of shapes and uniqueness of a product so that they can be reproduced - traded on the business incubator. However, based on the data from the business incubator, there was a decrease in the purchasing power of students who purchased the product in the business incubator in the year 2017 by $20 \%$ compared to the year 2016 . The questions finally appeared whether the student as a retailer of products already shared our knowledge of what was sought by a consumer to purchase a product which increases the performance of the business organization and whether students as a supplier of products already implemented the marketing capability to produce products that were attractive to prospective consumers and a performance of organization's business to be successful. It is very exciting to research the knowledge management in knowledge-sharing to create the desired products for prospective consumers and marketing capabilities to innovate the created the products.

Creating a quality product is influenced by the product knowledge that will be made. Knowledge is a source of organization that creates value and innovation. Some researchresults explain that business requires knowledge of the organization as a source to be studied and shared with all existing business organizations (Ahmed et al. 2014). Sharing knowledge is related to the learning organization "learning organization" (Tang et al. 2015). The quality of products produced by sharing knowledge is considered important for creating an innovative products through the uniqueness that is judged by the consumer as a business organization's ability to innovate in the development of the product (Hajli et al. 2017). In some results, a company introduced new products created through the ability to develop new products that have good quality to be introduced (Montgomery et al. 2012). In another case, a company is known to have a good product or has made limited changes to the product which has been marketed (Banerjee and Soberman, 2013). The company's ability to innovate can provide good judgment and maintain consumer loyalty as a collective assessment into the evaluation of the company as an innovative company (Foroudi et al. 2016). Business organizations that innovate in general are already defined as an organizational strategy that is open to new ideas and a new way - how to meet customer needs (Efrat et al. 2017). Strategy innovation to create new products has a significant ability to be utilized in achieving higher performance ( $\mathrm{Mu}, 2015)$. Abilities such as "emulated" often include superior knowledge about markets, customers and provide networks that are essential for designing and implementing strategies concerned with innovation to improve organizational performance ( $\mathrm{Yu}$ et al. 2017). Thus, a dynamic marketing can be resolved by sharing knowledge and marketing capabilities (Cacciolatti and Lee, 2016). The results of the above research are extremely complex with many different problems faced by business organizations with a variety of different settlements using variables interconnected with the object representing the available population, whereas research This is just taking the respondents from students who have the products sold in the business incubator at UPN "Veteran" of East Java. Various research results above make it clear that a dynamic marketing is a business organization challenge to be able to compete with other business organizations. This research will explain 
in more detail how business organizations are able to adapt to market changes to improve the performance of marketing through improved knowledge sharing and marketing capability of the business incubator at UPN "Veteran" of East Java.

Some of the literature collected explained how performance of marketing can be improved in the near future in which marketing continues to undergo changes. Business incubator at UPN "Veteran" of East Java is a place for students to sell products they produce and experience increase and continuation; however, a few months later, profit achieved by the business incubator had decreased. Some of the literature tells us that knowledge sharing and marketing capability as the deciding factors in which the students are able able to improve the performance of marketing in business units so that the hypotheses given are as follows. The first question: Does knowledge sharing that includes innovation capability and responsive capability have a significant effect on marketing performance? The second one: Do an innovation capability and responsive capability have a significant effect on marketing performance. The purposes of this study were to determine the effect of knowledge sharing, innovation capability, and responsive capability on marketing performance in Incubator Business at UPN "Veteran" Jawa Timur.

\section{METHODS}

The sample in this study were students who have a business and become suppliers in Business Incubator of UPN "Veteran" East Java. This study was conducted from June 2018 to July 2018. The study was only carried out by students as suppliers in Business Incubators. This research was an explanatory research that aimed to know the relationship between the research variables of knowledge sharing, innovation capability, responsive capability, and marketing performance. This study used primary data obtained directly from the respondents using a questionnaire method and questions were submitted and collected in writing, and the data were taken directly from the respondents related to this research.

Data collection in this study used a sampling technique of purposive sampling with certain criteria. First, the respondents were Business Administration Students; second, their age was > 17 years; third, their length of business was minimum of 1 year; finally, they were willing to fill out the questionnaire.

This research used the data analysis method using the softPLS version 2.0.m3 software that was run with computer media. Data analysis was conducted using Suction Equation Model (SEM) with Likert scale 7 level preference that is from strongly disagree of 1 to strongly agree of 7 . Variant-based structural equation analysis (SEM) is a kind of silmutan that can carry out measurement model testing while testing the structural model. The measurement model is used to test validity and reliability, while the structural model is used to test causality (testing hypotheses with prediction models).

Testing of item is an adaptation of instrument used in this research. Knowledge Sharing variable adapted from the research (Wang and Wang, 2012) shows that knowledge Sharing dimension is tacit knowledge and explicit knowledge. Tests of marketing capability variables are innovation capability and responsive capability. The innovation capability variable adapted from the research (Lai and Lin, 2012) shows innovation capability dimension of product development and market demand. The responsive capability variable adapted from the research (Tang et al. 2015) shows that the dimension of responsive capability, i.e. market changes. Therefore, to test the variables of marketing performance adapted from the research (Najafi et al. 2016), the dimension is divided into the volume of sales and the growth rate of sales.

The Influence of Knowledge Sharing on Innovation Capability

A knowledge-canteredactivity and fundamental way for an organization to share knowledge and contribute to the application of knowledge, innovation and competitive advantage in a business organization is knowledge sharing (Wang and Wang, 2012). Knowledge sharing is a tool for a business organization to gain knowledge and leads to changes in organizational behaviourand performance. Through effective sharing of knowledge and learning, business organizations can improve their behaviour, be able to innovate and organize organizational efficiency (Sulistyo and Siyamtinah, 2016). One benefit of knowledge sharing is to form an ability to innovate a business organization. Innovation capability is the ability of an organization to successfully create a product that has an impact on increasing sales, profits and competitive advantage in (Lai and Lin, 
2012). Some research findings show that knowledge sharing can give effects to business organizations in the ability to innovate. The research by Hu et al. (2009) showed that the knowledge sharing activities provided by small and medium entrepreneurs can add the ability to innovate of every business organization that is being hit by business competition. Therefore, based on the existing literature and theory, the following hypothesis can be formulated as follows: H1 (Knowledge sharing has a positive influence on innovation capability).

The Influence of Knowledge Sharing on Responsive Capability

Knowledge sharing as organizational knowledge becomes individual or organizational knowledge with a process of internalization and socialization (Chang et al. 2007). On the other hand, knowledge sharing can be provided to individuals and organizations based on externalization and combination processes. Knowledge sharing greatly helps the role of knowledge to respond quickly in the face of dynamic business competition so that it takes the ability to respond quickly to business changes (Tang et al.2015). The ability to respond quickly is also greatly influenced by knowledge sharing, which makes the business organization have the responsive capability (Ahmed et al. 2014). The responsive capability is very helpful for business organizations so that they have the ability to independently see the market situation and market stimulation to perform analysis and are able to respond quickly to market conditions (Angulo-Ruiz et al. 2018). The research (Hu et al. 2009) shows that business organizations need knowledge sharing to cultivate the organization in the ability to respond quickly to the current market situation. Therefore, based on the existing literature and theory, the following hypothesis can be formulated: H2 (Knowledge sharing has a positive influence on responsive capability).

The Influence of Knowledge Sharing on Marketing Performance

Knowledge sharing is a tool for an organization to gain knowledge and leads to changes in organizational behaviourand performance (Calix et al. 2015). Through effective sharing of knowledge and learning, business organizations can improve their behaviour, capability of innovation, and organizational efficiency to achieve marketing performance (Tang et al. 2015). Marketing performance is a concept used to measure and assess the extent to which market achievements have been achieved by a product produced by the business organization through marketing activities (Wu, 2015). Some researches showed that knowledge sharing gives effects on marketing performance by giving knowledge to business organization to develop marketing so as to generate significant marketing performance (Wang et al. 2016). Therefore, based on the existing literature and theory, the following hypothesis can be formulated: H3 (Knowledge sharing has a positive influence on marketing performance).

The Influence Marketing Capability on Marketing Performance

Marketing capability is the capability to use inputs and resources, such as financial resources and customer loyalty and efficiently generate desired sales. Marketing capability aims to generate a positive influence on the economic value made by business organizations by increasing market demand (Ahmed et al. 2014). Furthermore, marketing capability is an integrative process, in which a business organization uses tangible or intangible resources to comprehensively understand consumer needs, create products different from competitors and achieve superior brand equity (Yeşil et al. 2013). Marketing capability becomes an important source to enhance the competitive advantage of business organizations to improve marketing performance and create positive value for consumers and be able to help business organizations create and maintain strong relationships with customers Marketing capabilities create a strong brand image that enables a company to deliver superior performance (Nath et al. 2010). Superior performances in marketing capability that can be developed include innovation capability and responsive capability.The capability of business organizations to innovate can provide good judgment and retain consumer loyalty as a collective valuation that becomes an evaluation company to become an innovative company (Foroudi et al. 2016). Innovative business organizations are generally defined as an organizational strategy that opens up new ideas and new ways of meeting customer needs (Efrat et al. 2017). Innovative ideas will have a positive impact on business organizations to improve marketing performance. The capabilities of innovation provide a solution for business organizations to add value to the company and help marketing to increase profits. Marketing performance is a factor used to measure the impact of marketing activities directed to produce 
marketing performance such as sales volumes and sales growth rates as indicators of the success of capability in executing marketing strategies. Some studies suggest that innovation capabilities can have an effect on marketing performance with novelty that attracts consumers (Najafi-Tavani et al. 2016). One advantage of marketing capability is to pay attention to market conditions for more responses to the market situation to improve marketing performance. Responsiveness capability is the capability of a business organization to slaughter and analyse and respond quickly and positively to dynamic market changes whereas the responsive capabilityto markets can have a positive impact on marketing performance (Tang etal. 2015). The results explain that the responsive capability to markets has a positive impact on the sustainability of positive marketing performance results (Efrat et al. 2017). Therefore, based on the existing literature and theory, the following hypotheses can be made: H4 (Innovation Capability has a positive influence onMarketing Performance) and H5 (Responsive capability has a positive influence onMarketing Performance).

The research model (Figure 1) explains that the research conducted had 5 hypotheses that explained the relationship of each variable. The model of this research aims to clarify the relationship of knowledge sharing, innovation capability, responsive capability against marketing performance on business incubators of UPN "Veteran" of East Java. This research describes models that were conducted to test the hypotheses that have been formed based on the theory and literature to develop hypotheses of H1, H2, H3, H4 and H5. Overall, the hypothesis testing was conducted with the analysis techniques determined in this study.

\section{RESULTS}

\section{Demographic and Characteristics of Sample}

The results of this study showed respondents with male gender as much as $69 \%$ and female gender as much as $31 \%$. The respondents were categorized into the $15-20$ year age group as many as $43 \%$ and the $20-25$ year age group as many as $57 \%$. The length of business owned by the students within 1 year was 55 people or $55 \%$ and more than 1 year was 45 people or $45 \%$. Demographic and characteristics of sample $(\mathrm{N}=100)$ in Table 1.

Table 1. Demographic and characteristics of sample $(\mathrm{N}=100)$

\begin{tabular}{lcc}
\hline & Frequency & Percent (\%) \\
\hline Gender & & \\
Male & 69 & $69 \%$ \\
Female & 31 & $31 \%$ \\
Age & & \\
$15-20$ & 43 & $43 \%$ \\
$20-25$ & 57 & $57 \%$. \\
Business & & \\
1 year & 55 & $55 \%$ \\
$>1$ year & 45 & $45 \%$ \\
\hline
\end{tabular}

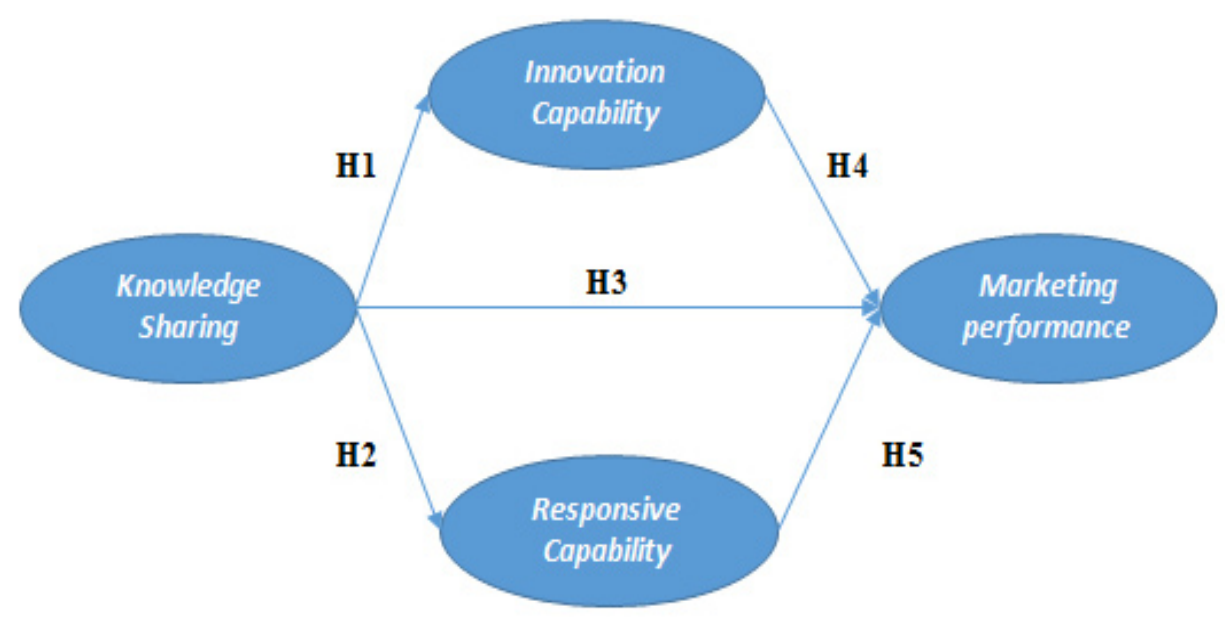

Figure 1. Research framework 
Table 2 shows that the overall value of the loading factor on each indicator item has met the criteria that is above 0.40 . The extracted variance shows the amount of variance of the indicators extracted by the developed variable. The high value of variance extracted indicates that the indicators have been well represented in the formation variables developed. Table 2 shows that from the result of variance extracted, all constructs have good AVE values because they have fulfilled the cut-off value that is equal to or above 0.50 . Reliability is one indicator of the validity of convergent. Many researchers also use Cronbach's alpha as a measure of reliability despite the fact that Cronbach's alpha provides lower reliability. Based on Table 2 it, can be seen that the value of composite reliability on each-each variable is $>0.7$, and the value of Cronbach's alpha on each-each variable is $>0.5$. Thus, it can be concluded that the data used in this study are reliable. Discriminant validity is a test to see if variable constructs are valid or not. The following is the result of correlation output between the construct variables in Table 3 which noted that the value of discriminant validity is $>0.6$ so that the overall variable constructs are valid.

Based on Figure 2, it is known that the highest coefficient value for a knowledge-sharing variable was KS6 of 0.721 which shows that KS6 had the strongest correlation among other indicators and KS5 had the lowest value of 0.457 . The innovation capability variable was IC1 of 0.918 which shows the strongest correlation among other indicators, and IC4 has the lowest value of 0.599 . The responsive capability variable that had the highest RC4 value of 0.779 indicates that $\mathrm{RC} 4$ had the strongest correlation among other indicators, and $\mathrm{RC} 2$ had the lowest value of 0.438 . The highest value of marketing performance was MF4 of 0.698 which shows that MF4 had the strongest correlation among other indicators, and MF 1 had the lowest value of 0.572. The hypothesis testing using the data PLS-SEM in Table 4.

Table 2. Descriptive statistics, indicator loadings, critical ratios, cronbach's alpha (A) and ave values

\begin{tabular}{|c|c|c|c|c|c|}
\hline & Item & $\begin{array}{c}\text { Convergent } \\
\text { Validity }\end{array}$ & Construct Reliability & AVE & Cronbach's Alpha \\
\hline \multirow{5}{*}{$\begin{array}{l}\text { Knowledge } \\
\text { Sharing (KS) }\end{array}$} & KS2 & 0.654 & 0.732 & 0.561 & 0.570 \\
\hline & KS4 & 0.457 & & & \\
\hline & KS5 & 0.457 & & & \\
\hline & KS6 & 0.721 & & & \\
\hline & KS7 & 0.658 & & & \\
\hline \multirow{4}{*}{$\begin{array}{l}\text { Innovation } \\
\text { Capability (IC) }\end{array}$} & $\mathrm{IC} 1$ & 0.918 & 0.896 & 0.687 & 0.850 \\
\hline & IC2 & 0.917 & & & \\
\hline & IC3 & 0.841 & & & \\
\hline & IC4 & 0.599 & & & \\
\hline \multirow{5}{*}{$\begin{array}{l}\text { Responsive } \\
\text { Capability (RC) }\end{array}$} & $\mathrm{RC} 1$ & 0.490 & 0.783 & 0.542 & 0.686 \\
\hline & $\mathrm{RC} 2$ & 0.438 & & & \\
\hline & $\mathrm{RC} 3$ & 0.745 & & & \\
\hline & $\mathrm{RC} 4$ & 0.779 & & & \\
\hline & $\mathrm{RC} 5$ & 0.752 & & & \\
\hline \multirow{5}{*}{$\begin{array}{l}\text { Marketing } \\
\text { Performance } \\
\text { (MP) }\end{array}$} & MP1 & 0.572 & 0.817 & 0.575 & 0.726 \\
\hline & MP2 & 0.605 & & & \\
\hline & MP3 & 0.763 & & & \\
\hline & MP4 & 0.781 & & & \\
\hline & MP5 & 0.698 & & & \\
\hline
\end{tabular}

Note: $\mathrm{CA}^{1 / 1} 4$ : Cronbach's alpha; $\mathrm{CR}^{1 / 4}$ : Composite Reliability; AVE1/4: Average Variance Extracted 
Table 3. measurement model discriminant validity

\begin{tabular}{lcccc}
\hline & Knowledge sharing & Innovation capability & Responsive capability & Marketing performance \\
\hline Knowledge sharing & 0.600 & & & \\
Innovation capability & & 0.829 & & \\
Responsive capability & & & 0.925 & 0.657 \\
Marketing & & & \\
performance & & & & \\
\hline
\end{tabular}

Table 4. Path coefficients (Mean, Stdev. and T-Values)

\begin{tabular}{lccccc}
\hline & Original Sample (O) & Sample Mean $(\mathrm{M})$ & $\begin{array}{c}\text { Standard Deviation } \\
(\text { STDEV.) }\end{array}$ & $\begin{array}{c}\text { T-Statistics }(\mid \mathrm{O} / \\
\text { STDEV } \mid)\end{array}$ & P-Value \\
\hline $\mathrm{KS} \rightarrow \mathrm{IC}$ & -0.302 & -0.320 & 0.153 & 1.678 & 0.058 \\
$\mathrm{KS} \rightarrow \mathrm{RC}$ & 0.173 & 0.170 & 0.064 & 2.699 & 0.007 \\
$\mathrm{KS} \rightarrow \mathrm{MP}$ & 0.456 & 0.485 & 0.084 & 5.458 & 0.043 \\
$\mathrm{IC} \rightarrow \mathrm{MP}$ & 0.009 & 0.006 & 0.035 & 0.263 & 0.792 \\
$\mathrm{RC} \rightarrow \mathrm{MP}$ & 0.849 & 0.850 & 0.038 & 22.144 & 0.000 \\
\hline
\end{tabular}

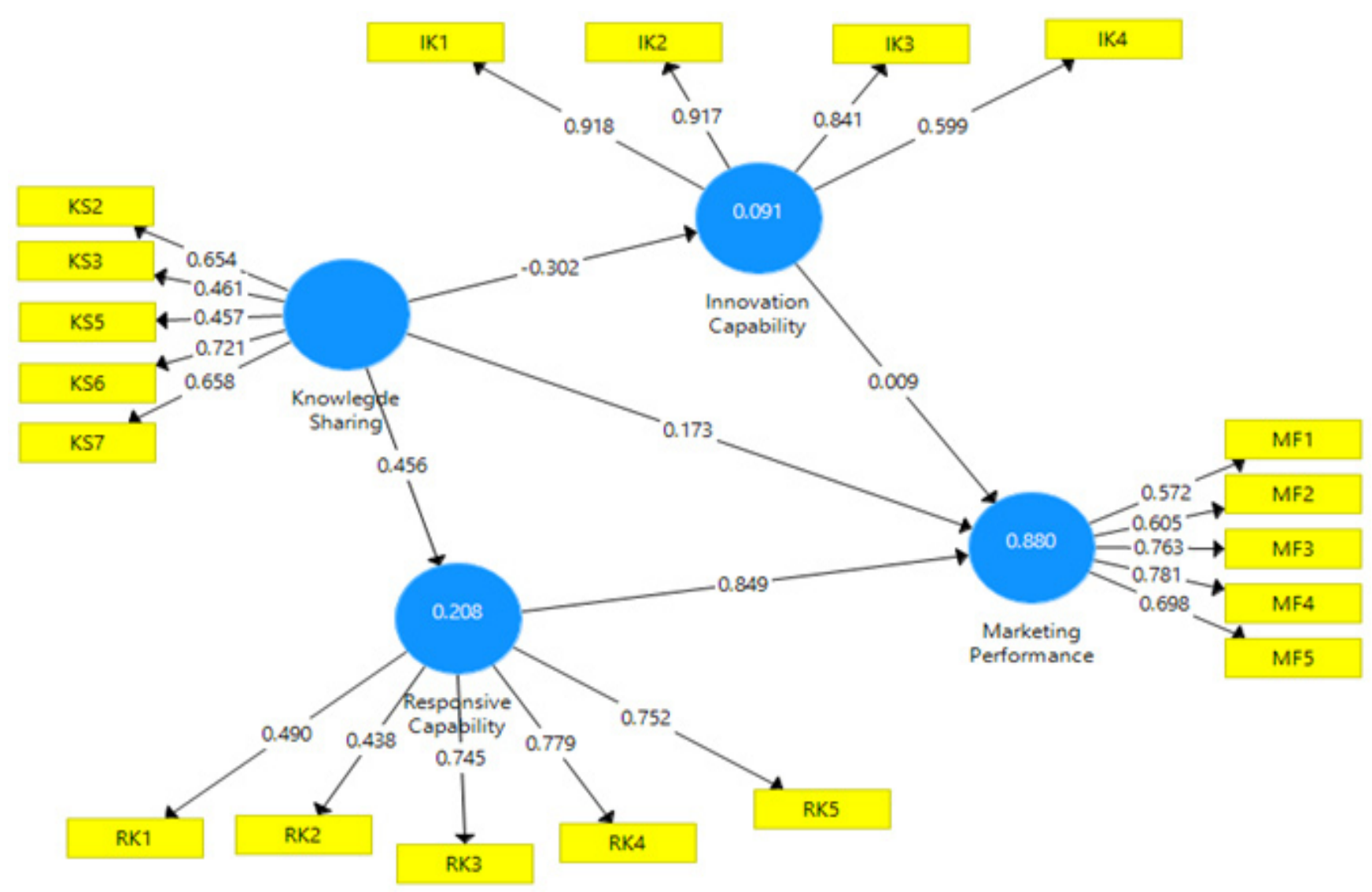

Figure 2. The result PLS-SEM alogaritm 
Based on Table 4, the effect of KS on IC is that more activities organized through training and assistance in the business incubator had good impacts to motivate students in creating innovative products. However, it does not affect the relationship of KS to IC with original sample value of -0.302 . Influence between $\mathrm{KS}$ to $\mathrm{RC}$ that is more accompaniment activities held in a business incubator through KS made the students obtain knowledge in order to form good $\mathrm{RC}$ for product development to face dynamic market condition by proving original sample of 0.173 . The effect of KS on MP shows that more information received by students about the development of marketing through seminars and workshops conducted in the business incubator, and this gave a positive impact to the marketing performance of each business unit owned by the students by proving the original sample of 0.456 . IC affected the MP, and the better the IC owned by the business unit of students, the more satisfied the consumers with the development of product types. To increase the productivity of the business unit, MP successfully proved the original sample of 0.009 . The influence of RC on MP is that the better responsiveness made by the business unit owned by the students; the more positive the impact on the marketing performance carried out through the products in accordance with the demand and market changes.

\section{The Impact of Knowledge Sharing on Innovation Capability}

Based on the results (Table 5) of the first hypothesis testing, it is known that the significance value of tobtained was at $0.000<0.058$, meaning that the first hypothesis was rejected with a statistical $t$ value of $1.678<t$ table (1.973). Therefore, there is no positive influence of knowledge sharing on innovation capability. Sharing knowledge is an activity that leads to the change and development of science including the development of innovative products that can provide satisfaction to consumers. Increasingly sharing knowledge of business organizations including business incubators will have a positive impact on students' ability to create innovative products. Thus, the results of this research show that knowledge sharing has insignificant effect on innovation capability because business incubators as a place to share knowledge are considered to lack activities that provide teaching to students so that they can provide innovative ideas and ideas. The results of this study are not in line with previous study conducted by (Hu et al. 2009).

\section{The Impact of Knowledge Sharing on Responsive Capability}

Based on results (Table 5) of the second hypothesis testing, it is known that the significance value obtained was at $0.000<0.007$, meaning that the second hypothesis was accepted with a statistical $t$ value of $2.699>t$ table (1.973). Thus, there is a positive and significant influence of $\mathrm{KS}$ on $\mathrm{RC}$, and the higher the $\mathrm{KS}$, the higher the RC. Knowledge Sharing (KS) is a place for business people or in this case, the students to obtain information of knowledge and technology to contribute to a product in order to analyse market condition. Therefore, consumer desire in accordance with market demand can be identified so that the students have Responsive Capacity (RC) in facing the dynamic market situation. The more often the training is conducted in sharing knowledge, the more significant the improvement the Innovation Capability (IC). The result of this research proves empirically that there is an influence of Knowledge Sharing (KS) on Responsive Capability (RC). The results of this study support or are consistent with previous research conducted by Research (Hu et al. 2009).

Table 5 . Resuls of hypothesis testing

\begin{tabular}{llcc}
\hline Hypothesis & & P-Value & Result \\
\hline H1: Knowledge sharing $\rightarrow$ Innovation capability & 0.058 & Insignificant \\
H2: Knowledge sharing $\rightarrow$ Responsive capability & 0.007 & Significant \\
H3: Knowledge sharing $\rightarrow$ Marketing performance & 0.043 & Significant \\
H4: Innovation capability $\rightarrow$ Marketing performance & 0.792 & Insignificant \\
H5: Responsive capability $\rightarrow$ Marketing performance & 0.000 & Significant \\
\hline
\end{tabular}




\section{The Impact of Knowledge Sharing on Marketing Performance}

Based on the result (Table 5) of the third hypothesis testing, it is known that the significance value of $t$ obtained was $0.000<0.043$, indicating that the third hypothesis was accepted with $t$ statistic value of $5.458>t$ table (1.973). Thus, there is a positive and significant influence of KS on MP, and the higher value of KS will increase the MP. If a business organization including a business unit owned by a student holds a discussion forum such as the concept of knowledge sharing, it will help students in marketing a product from various marketing concepts and marketing strategies of the present time so as to improve marketing performance that leads to the profitability of the organization. The result of this research proves empirically that there is an influence of Knowledge Sharing (KS) on Marketing Performance (MP). The results of this study support or are consistent with previous research conducted by Research (Tang et al. 2015) stating that knowledge sharing gives influence on marketing performance caused by the provision of knowledge to the business unit to develop marketing to produce good marketing performance (Tang et al. 2015).

\section{The Impact of Innovation Capability on Marketing Performance}

Based on the results (Table 5) of the fourth hypothesis testing, it is known that the significance value of $t$ obtained was at $0.000>0.792$, indicating that the fourth hypothesis was rejected with a statistical $t$ value of $0.263<\mathrm{t}$ table (1.973). Therefore, there is no positive influence of IC on MP. The more innovative products that match the market demand will have an impact on the demand so that the purchase occurs, and it can be said that the marketing performance goes significantly well including Incubator Business at UPN "Veteran" East Java. The results of this research prove empirically that there is an influence of Innovation Capability (IC) on Marketing Performance (MP). The results of the research described above only apply to the parameters of this study, with all the limitations of the survey on Incubator Business. The results of this study support or are consistent with previous research conducted by (Najafi et al. 2016).

\section{The Impact of Responsive Capability on Marketing Performance}

Based on the result (Table 5) of the fifth hypothesis testing, it is known that the significance value of $\mathrm{t}$ obtained was at $0.000>0.000$, meaning the fifth hypothesis is accepted with the value of $t$ statistic of $22.144>t$ table (1.973). Thus, there is a positive and significant influence of RC on MP in which the higher $\mathrm{RC}$ will greatly increase MP. The ability to respond to dynamic markets is important in identifying the diverse market demands. This capability must be owned by every business unit including student business which must keep abreast of market demands, demanding varied products according to consumer wishes. This ability is judged to have a good impact on improving product sales so that marketing performance increases as the product sales increase in the market in accordance with market dynamics. The result of this research proves empirically that there is an influence of Innovation Capability (IC) on Marketing Performance (MP). The results of this study support or are consistent with previous research conducted by (Efrat et al. 2017).

\section{Managerial Implications}

The implications of this study include the provision of deeper understanding on how to apply management knowledge in the business carried out especially for students who will create products/services and attention by students as business objects in this study on innovations and responses to market conditions that continue to make changes; therefore, a market is carried out effectively and efficiently.

\section{CONCLUSIONS AND RECOMMENDATION}

\section{Conclusions}

This research was conducted to know the relationship between knowledge sharing and marketing capability to marketing performance in Incubator Business at UPN "Veteran" East Java. First, the results show that knowledge sharing has a positive and significant impact on the marketing capability that is responsive capability, but has insignificant effect on innovation capability (H1 was rejected and $\mathrm{H} 2$ was proven). Knowledge sharing as a process to provide information through a business seminar forum and business training to grow students' ideas to produce innovative and fast products 
to respond to market changes and market demand, and the results of this research show that knowledge sharing has an insignificant effect on innovation capability because business incubators as a place to share knowledge are considered to lack activities that provide teaching to students so that they can provide innovative ideas. Second, knowledge sharing has a positive and significant impact on marketing performance (H3 has been proven). Knowledge sharing provides information on how to produce products in accordance with market developments and market demand so that sales increase as increasing fees prove that marketing performance is successful through the strategies gained when sharing knowledge plays a role. Third, Marketing capability as the ability of business units to introduce products to create good value impact marketing performance. If marketing capability in a business unit is good, then marketing performance will also be good. However, marketing capability in this research shows that innovation capability cannot affect marketing capability (H4 was rejected). This is because business units in the Business Incubator cannot meet market demand and follow market development so that marketing performance can be said less effective in product development. On the other hand, the responsive capability has a positive and significant effect on marketing capability (H5 has been proven). Responsive capability is a business unit ability to respond to dynamic market developments to meet market demands that change over time, thus affecting marketing performance.

\section{Recommendations}

Recommendation in this research is that business unit must follow various activities regarding the development of knowledge on market changes and consumer behaviour. Therefore, knowledge sharing activities take place, and it is expected that the materials given should be in accordance with the needs of existing business units so that they can contribute greatly to the business units. This research is expected to provide benefits on the management of business units that prioritize knowledge management in the development of business. Knowledge sharing that is often done through business seminars and business training is expected to improve the ability of students in managing the business units. Capability to market innovative products in accordance with market developments through responsive capability will make sales of business units increase and succeed marketing performances.

\section{REFERENCES}

Ahmed MU, Mehmet MK, Mark. 2014. Impact of operational and marketing capabilities on firm performance: evidence from economic growth and downturns. International Journal of Production Economics 154:59-71. https://doi. org/10.1016/j.ijpe.2014.03.025.

Angulo-Ruiz F et al. 2018. How does marketing capability impact abnormal stock returns? the mediating role of growth. Journal of Business Research 82(March 2017):19-30. https://doi. org/10.1016/j.jbusres.2017.08.020.

Banerjee S, Soberman DA. 2013. Product development capability and marketing strategy for new durable products. International Journal of Research in Marketing 30(3):276-91. https:// doi.org/10.1016/j.ijresmar.2013.01.003.

Cacciolatti L, Lee SH. 2016. Revisiting the relationship between marketing capabilities and firm performance: the moderating role of market orientation, marketing strategy and organisational power. Journal of Business Research 69(12):5597-5610. https://doi. org/10.1016/j.jbusres.2016.03.067.

Calix CG, Hernán PV, Anahí EB. 2015. Capital intelectual y otros determinantes de la ventaja competitiva en empresas exportadoras de la zona norte de honduras. Suma de Negocios 6(14):130-37.https://doi.org/10.1016/j. sumneg.2015.10.005.

Chang J, Chun CH, Ching L. 2007. Working hours reduction and wage contracting style in a dynamic model with labor adjustment costs. Journal of Economic Dynamics and Control 31(3):971-93. https://doi.org/10.1016/j.jedc.2006.02.001.

Chenic(Cretu) et al. 2013. Working Working time - a key element of health workers, an instrument of labor market flexibility, the situation of the health system. Procedia - Social and Behavioral Sciences 93:1142-47. https://doi.org/10.1016/j. sbspro.2013.10.004.

Efrat K, Shaked G, Moshe Y. 2017. When marketing and innovation interact: the case of born-global firms. International Business Review 26(2):380-90. https://doi.org/10.1016/j.ibusrev.2016.09.006.

Foroudi P et al. Mohammad MF 2016. Influence of innovation capability and customer experience on reputation and loyalty. Journal of Business Research 69(11):4882-89. https://doi. 
org/10.1016/j.jbusres.2016.04.047.

Hajli $\mathrm{N}$ et al. 2017. Branding co-creation with members of online brand communities. Journal of Business Research 70:136-44. https://doi.org/10.1016/j. jbusres.2016.08.026.

Hu MM, Jeou-shyan H, Yu-hua CS. 2009. Hospitality teams: knowledge sharing and service innovation performance. Tourism Management 30(1):41-50. https://doi.org/10.1016/j.tourman.2008.04.009.

Kladou S et al. 2017. The role of brand elements in destination branding. Journal of Destination Marketing and Management 6(4):426-35. https://doi.org/10.1016/j.jdmm.2016.06.011.

Lai YL, Feng-Jyh L. 2012. The effects of knowledge management and technology innovation on new product development performance an empirical study of taiwanese machine tools industry. Procedia - Social and Behavioral Sciences 40:157-64. https://doi.org/10.1016/j. sbspro.2012.03.176.

Montgomery KC et al. 2012. The new threat of digital marketing. Pediatric Clinics of North America 59(3):659-75.https://doi.org/10.1016/j. pcl.2012.03.022.

$\mathrm{Mu}$ J. 2015. Marketing capability, organizational adaptation and new product development performance. Industrial Marketing Management 49:151-66.https://doi.org/10.1016/j. indmarman.2015.05.003.

Najafi-Tavani S, Hossein S, Zhaleh N. 2016. Market orientation, marketing capability, and new product performance: the moderating role of absorptive capacity. Journal of Business Research 69(11):5059-64.https://doi.org/10.1016/j. jbusres.2016.04.080.

Nath P, Subramanian N, Ramakrishnan R. 2010. The impact of marketing capability, operations capability and diversification strategy on performance: a resource-based view. Industrial Marketing Management 39(2):317-29. https:// doi.org/10.1016/j.indmarman.2008.09.001.
Prayogo RR, Nirawati L. 2017. The triangle of knowledge sharing, e-marketing capability, marketing performance. Jurnal Ilmiah Bidang Akuntansi dan Manajemen 16(1):22-33. https:// doi.org/10.31106/jema.v16i1.1593.

Sulistyo H, Siyamtinah. 2016. Innovation capability of smes through entrepreneurship, marketing capability, relational capital and empowerment. Asia Pacific Management Review 21(4):196-203. https://doi.org/10.1016/j.apmrv.2016.02.002.

Tang TP, Xiaorong F, Qinghong X. 2015. Influence of functional conflicts on marketing capability in channel relationships. Journal of Business Research 78:252-60. https://doi.org/10.1016/j. jbusres.2016.12.020.

Wang Z, Pratyush NS, Jinwei C. 2016. From knowledge sharing to firm performance: a predictive model comparison. Journal of Business Research 69(10):4650-58.https://doi.org/10.1016/j. jbusres.2016.03.055.

Wang Z, Nianxin W. 2012. Knowledge sharing, innovation and firm performance. Expert Systems with Applications 39(10):8899-8908. https://doi. org/10.1016/j.eswa.2012.02.017.

$\mathrm{Wu}$ CW. 2015. The international marketing strategy modeling of leisure farm. Journal of Business Research 69(4):1345-50. https://doi. org/10.1016/j.jbusres.2015.10.105.

Yeşil S, Alaeddin K, Tuba B. 2013. Knowledge sharing process, innovation capability and innovation performance: an empirical study. Procedia Social and Behavioral Sciences 75:217-25. https://doi.org/10.1016/j.sbspro.2013.04.025.

Yu W, Ramakrishnan R, Prithwiraj N. 2017. Environmental pressures and performance: an analysis of the roles of environmental innovation strategy and marketing capability. Technological Forecasting and Social Change 117:160-69. https://doi.org/10.1016/j.techfore.2016.12.005. 